Archive for

Organic Chemistry

Arkivoc 2017, part iii, 293-301

\title{
New reactions and reactive intermediates in the pyrolysis of cyclic phosphonium ylides
}

\author{
R. Alan Aitken, ${ }^{* a}$ Vidar Bjørnstad, ${ }^{\text {b }}$ Tracy Massil, ${ }^{a}$ Jan Skramstad, ${ }^{b}$ and Robert J. Young ${ }^{c}$ \\ ${ }^{a}$ EaStCHEM School of Chemistry, University of St Andrews, North Haugh, St Andrews, Fife, KY16 9ST, UK \\ ${ }^{b}$ Department of Organic Chemistry, University of Oslo, P.O. Box 1033, Blindern, N-0315, Oslo, Norway \\ ${ }^{c}$ GSK Medicines Research Centre, Gunnels Wood Road, Stevenage, SG1 2NY, UK \\ Email: raa@st-and.ac.uk
}

\section{Dedicated to Professor Oleg A. Rakitin on the occasion of his 65th birthday}

Received 06-04-2017

Accepted 07-13-2017

Published on line 08-31-2017

\begin{abstract}
Pyrolysis, either neat or in diphenyl ether solution, results in the conversion of both 4triphenylphosphoranylidenetetrahydrofuran-2,3,5-trione and 4-triphenylphosphoranylidenetetrahydrothio-phene-2,3,5-trione into 3,5-bis(triphenylphosphoranylidene)cyclopentane-1,2,4-trione. These reactions involve extrusion of $\mathrm{CO}_{2}$ or $\mathrm{COS}$ to give 3-triphenylphosphoranylidenecyclopropane-1,2-dione which further loses $\mathrm{CO}$ to give triphenylphosphoranylideneketene. The precise way in which these two reactive phosphorus compounds combine to give the observed product has been examined by chemical and isotopic labelling studies. Cyclotrimerization of triphenylphosphoranylideneketene upon thermolysis in diphenyl ether has also been observed for the first time. The erroneous literature interpretation of the ${ }^{13} \mathrm{C} N M R$ spectrum for triphenylphosphoranylideneketene is corrected.
\end{abstract}

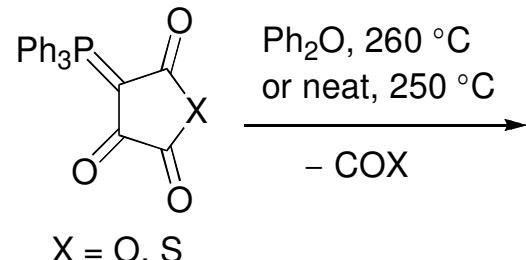<smiles>O=C1C(=P)C(=O)C(=P)C1=P</smiles>

$X=O, S$

Keywords: Cyclic ylides, pyrolysis, phosphoranes, reactive intermediates 


\section{Introduction}

We recently introduced the value of the two-bond NMR coupling constant ${ }^{2} J_{P-C O}$ as a diagnostic parameter for the reactivity of $\beta$-oxophosphonium ylides 1 towards thermal extrusion of $\mathrm{Ph}_{3} \mathrm{PO}$ to give alkynes (Scheme 1). ${ }^{1}$ All known ylides that do undergo such extrusion to form an alkyne have ${ }^{2} \mathrm{~J}_{\mathrm{P}-\mathrm{co}}<11 \mathrm{~Hz}$, while those with values above this do not. The latter group includes formyl and alkoxycarbonyl ylides $\left(R^{2}=H, O-A l k y l\right)$ where the failure of extrusion as well as the high $J$ value is associated with the $\mathrm{C}=\mathrm{P}$ and $\mathrm{C}=\mathrm{O}$ functions being aligned anti rather than syn to one another. However the rule also applies to ylides where the functions are constrained syn such as the cyclic examples $\mathbf{2}$ and $\mathbf{3}$. With a $J$ value of $11.3 \mathrm{~Hz}, \mathbf{2}$ does not undergo extrusion under any circumstances whereas 3 with a value of $3.7 \mathrm{~Hz}$ readily eliminates $\mathrm{Ph}_{3} \mathrm{PO}$ upon flash vacuum pyrolysis (FVP) at $750^{\circ} \mathrm{C}$ to give products derived from cyclohexyne. ${ }^{1}$

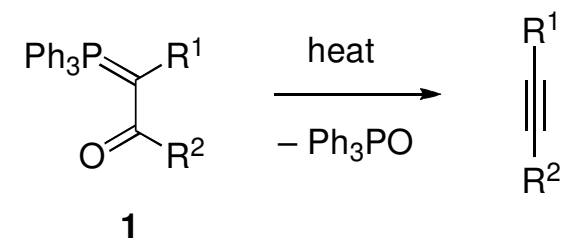

1

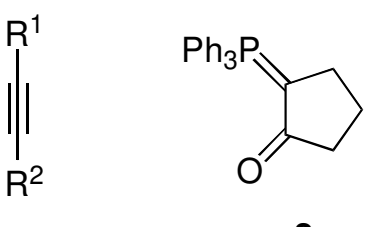

2

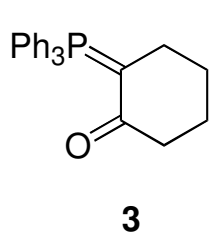

3

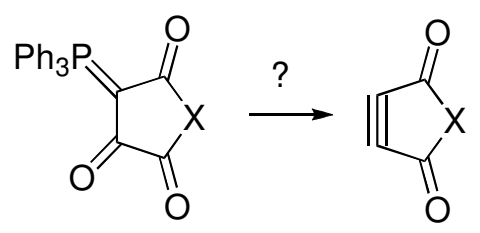

$4 X=0$

$5 X=S$

\section{Scheme 1}

A wide range of heterocyclic phosphonium ylides are known, ${ }^{2,3}$ and among those with published ${ }^{2} J_{p-c o}$ values, our attention was drawn to ylide 4 and its thio-analogue 5 . These are readily prepared from dichloromaleic (thio)anhydride and, with ${ }^{2} J_{P-c o}$ values for the ketone carbonyl of $8 \mathrm{~Hz}^{4}$ and $7 \mathrm{~Hz}^{5}$ respectively, seemed possible precursors for thermal generation of dehydromaleic anhydride and its thio analogue. Such heterocyclic alkynes are elusive and highly reactive compounds that have attracted considerable interest, ${ }^{6}$ and we describe here for the first time the thermal decomposition of $\mathbf{4}$ and $\mathbf{5}$.

\section{Results and Discussion}

In fact, FVP of both $\mathbf{4}$ and $\mathbf{5}$ gave disappointing results, with the only products obtained in the cold trap being a trace of $\mathrm{Ph}_{3} \mathrm{PO}$ in the first case and a mixture of $\mathrm{Ph}_{3} \mathrm{PO}, \mathrm{Ph}_{3} \mathrm{PS}, \mathrm{Ph}_{3} \mathrm{P}$ and triphenylphosphoranylideneketene 11 in the second. However there was also substantial decomposition in the inlet tube and analysis of the residue from attempted FVP of 4 at $200{ }^{\circ} \mathrm{C}$ showed it, most surprisingly, to be the trioxo bis(ylide) 6 (10\%) previously reported by Bestmann and co-workers. ${ }^{7}$ This must obviously be formed by an intermolecular process and, once this was clear, much better results could be obtained by heating $\mathbf{4}$ or $\mathbf{5}$ in a small volume of boiling diphenyl ether (bp $260^{\circ} \mathrm{C}$ ) for $24 \mathrm{~h}$ or in the case of 4 by heating the neat material at $250{ }^{\circ} \mathrm{C}$ for $3 \mathrm{~h}$. In each case the major product was the trioxo bis(ylide) 6 which was readily identified by its characteristic NMR spectra $\left[\delta_{\mathrm{p}}+9.0 ; \delta_{\mathrm{C}} 196.4(\mathrm{t}, J 10)\right.$ and $\left.187.6(\mathrm{dd}, J 20,6)\right]$ and also by comparison with an authentic sample.

There are several mechanistic possibilities for the formation of this unexpected product (Scheme 2). It seems likely that either $\mathrm{CO}_{2}$ or $\mathrm{COS}$ is first lost to give the triphenylphosphoranylidenecyclopropanedione 7 which may then dimerise probably by way of the dipolar ring-opened forms $\mathbf{9}$ or $\mathbf{1 0}$ to give $\mathbf{8}$ and this could then lose $\mathrm{CO}$ to give $\mathbf{6}$. Of course the diradical intermediates corresponding to $\mathbf{9}$ or $\mathbf{1 0}$ could also be considered but these seem less likely in view of the highly polar groups present. A second major possible route is for $\mathbf{7}$ to 


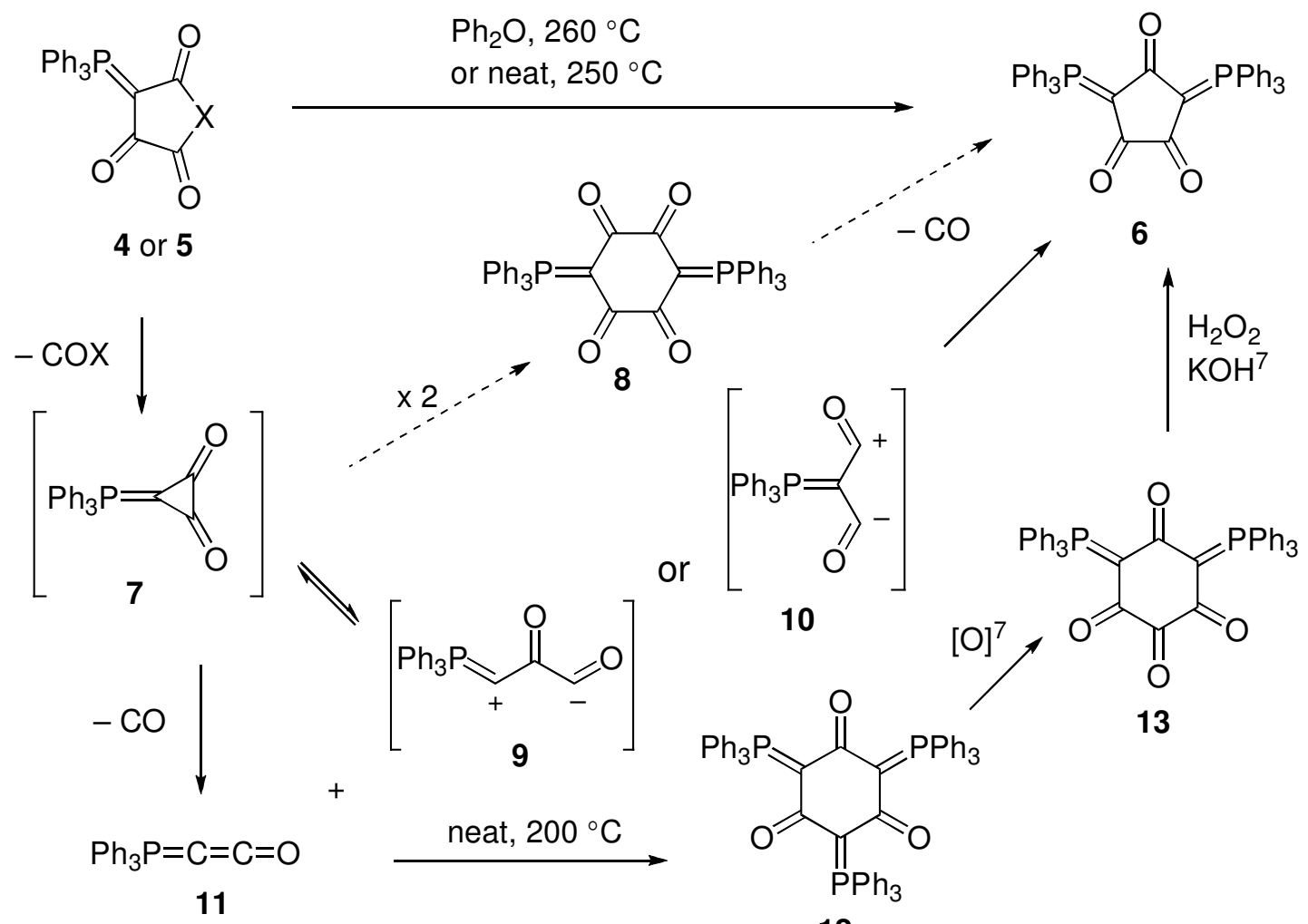

\section{Scheme 2}

lose CO to give $\mathbf{1 1}$ which can then undergo direct cycloaddition with $\mathbf{9}$ or $\mathbf{1 0}$ to give $\mathbf{6}$. Evidence in favour of the latter pathway was provided by heating an equimolar mixture of 4 and $11^{8,9}$ in boiling diphenyl ether for $2 \mathrm{~h}$, which led to formation of 6 as the only phosphorus-containing product. Interestingly a control experiment of heating 11 alone for 30 min under these conditions led to formation of its cyclic trimer $12\left(\delta_{p}+13.9\right)$ which was previously obtained by Bestmann and co-workers by a different route. ${ }^{7}$ We can thus conclude that whatever intermediate (9 or $\mathbf{1 0}$ ) is being formed by $\mathbf{4}$ in its decomposition to $\mathbf{6}$ reacts efficiently with added $\mathbf{1 1}$ to give the same product. Compound $\mathbf{6}$ was previously prepared by $\mathrm{HCl}$ catalysed trimerisation of $\mathbf{1 1}$ to give 12 which was then subjected to oxidation by 2-tosyl-3-phenyloxaziridine to afford the tetraoxo bis(ylide) 13 . This underwent oxidative ring-contraction upon treatment with hydrogen peroxide and $\mathrm{KOH}$ to afford 6. However an additional lower-yielding route to 6 is the treatment of ethyl triphenylphosphoranylidenepyruvate 14 with sodium hexamethyldisilazide to give the product in $4 \%$ isolated yield (Scheme 3). ${ }^{10}$ This was carried out in the expectation of isolating 7 and, although the author proposed that $\mathbf{6}$ was formed by a different route not involving 7, the new evidence presented here makes it likely that this route may also proceed by initial baseinduced elimination of ethanol from 14 to give $\mathbf{7}$ which thereafter reacts as shown in Scheme 2 to give 6 .<smiles>CCOC(=O)C(=O)C=[Pb]</smiles>

14

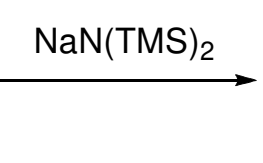

Scheme 3

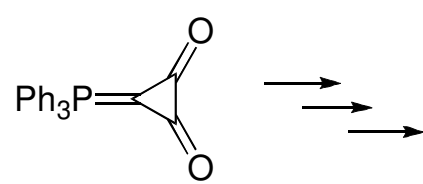

7<smiles>O=C1C(=P)C(=O)C(=P)C1=P</smiles>

6 
In order to differentiate between the possible modes of bond breaking in 7, we first attempted chemical labelling by preparing a tri-p-tolyl analogue. We were unable to obtain the tri-p-tolyl analogue of $\mathbf{4}$ but the tri-p-tolyl analogue of 11, compound 17, was prepared as shown in Scheme 4. Ethyl bromoacetate was reacted with tri- $p$-tolylphosphine ${ }^{11}$ to give the salt $\mathbf{1 5}$ and treatment of this with sodium hydroxide gave the new stabilised ylide 16 , which was fully characterised.

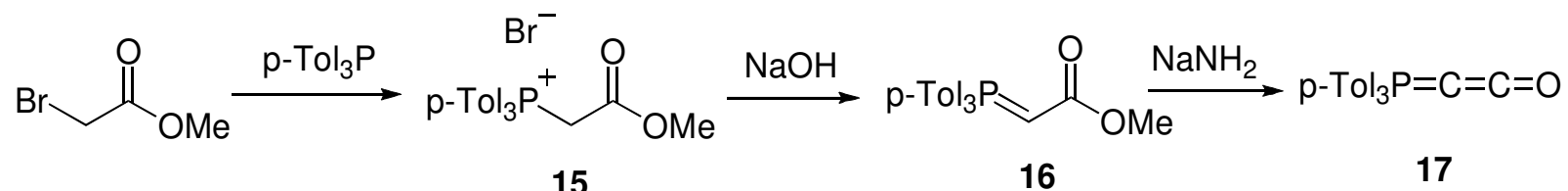

\section{Scheme 4}

When this was reacted with sodium amide in toluene a new product with characteristic NMR signals at $\delta_{\mathrm{P}}+5.3$ and $\delta_{\mathrm{C}} 142.6(\mathrm{~d}, J 39, \mathrm{P}=\mathrm{C}=\underline{\mathrm{C}}=\mathrm{O})$ attributed to 17 was formed. However heating this under a wide variety of conditions, either with or without added $\mathbf{4}$, did not lead to formation of a $p$-tolyl analogue of 6 and tri- $p$-tolylphosphine oxide was the only identifiable product derived from $\mathbf{1 7 .}$

We then resorted to isotopic labelling and prepared $20 \%{ }^{13} \mathrm{C}$-labelled methoxycarbonyl ylide 19 by the literature method ${ }^{12}$ starting from labelled methyl bromoacetate via the phosphonium salt 18 (Scheme 5).

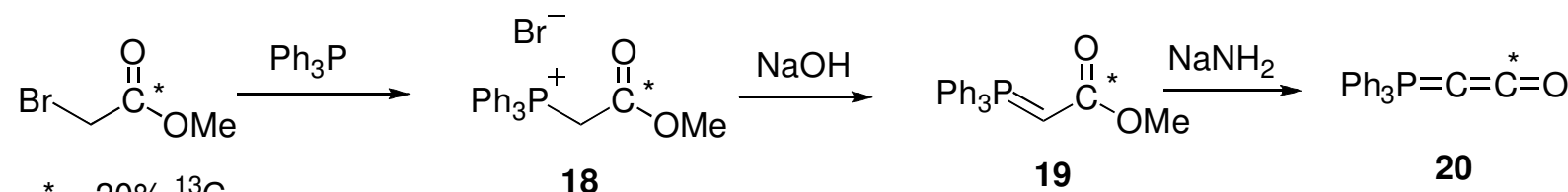

\section{Scheme 5}

When this was heated in diphenyl ether with 4 the resulting sample of the trioxo bis(ylide) proved to be the isomer $\mathbf{2 1}$ with the label at the isolated carbonyl (ca. $20 \mathrm{x}$ enhancement of signal at $\delta_{\mathrm{C}} 196.4$ compared to $\delta_{c}$ 187.6) and not the isomer 22, thus showing conclusively that it is the intermediate 9 or its diradical analogue rather than 10 which reacts with 11 to give 6 .

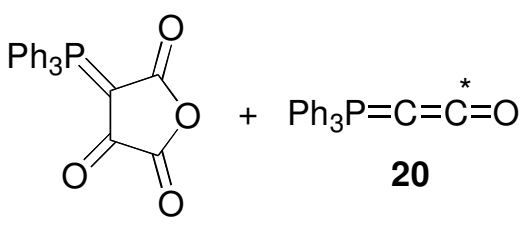

4
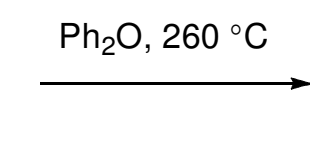<smiles>O=C1C(=O)C(=P)C(=O)C1=P</smiles>

21<smiles>O=C1C(=O)C(=P)C(=O)C1=P</smiles>

22

\section{Scheme 6}

We cannot however exclude the possibility that, in the absence of added 11, formation of 6 is by dimerisation of an intermediate, probably $\mathbf{9}$, to give $\mathbf{8}$ which then loses CO. Whichever mechanism is operating, it should be possible to trap the intermediates with other added dipolarophiles leading to new types of stabilised ylides and this is currently being examined.

Finally, in the course of this study we have become aware of conflicting information regarding the ${ }^{13} \mathrm{C}$ NMR spectrum of triphenylphosphoranylideneketene 11. This compound was first reported by Birum and Matthews, ${ }^{13,14}$ but was later obtained in a more convenient way by base-induced elimination of methanol 
from methoxycarbonylmethylenetriphenylphosphorane as shown in Scheme 5. ${ }^{8,9}$ There are three literature reports of its ${ }^{13} \mathrm{C}$ NMR spectrum and there is widespread agreement on the rather remarkable chemical shifts of the ketene carbons $\left[\delta_{C}-10.5(d, J 189, P=C), 145.6(d, J 43, P=C=C=0)\right]$. The situation for the P-phenyl signals is however confused as summarised in Table 1 with erroneous data shaded. Analysis of the ${ }^{13} \mathrm{C}$ NMR spectra of nearly 200 stabilised triphenylphosphonium ylides, ${ }^{1}$ shows that the P-phenyl signals form a regular pattern with the ipso-C having a large coupling constant to phosphorus of between 90 and $100 \mathrm{~Hz}$, the ortho-C coming around 132-133 ppm with a coupling constant of 9-11 Hz, the meta-C coming around 128-129 ppm with a larger coupling constant of $12-13 \mathrm{~Hz}$, and the para-C around $132 \mathrm{ppm}$ with a coupling constant of $0-2 \mathrm{~Hz}$. The main problem in correctly interpreting the spectrum of $\mathbf{1 1}$ is the close proximity of the ortho and para signals and partial or complete overlap of one half of the ortho doublet with the para singlet giving two apparent singlets. The previous reports have all made this mistake, ${ }^{9,15,16}$ with two also interchanging the ortho and meta signals. ${ }^{9,16}$ The corrected data as obtained in our work is shown and this agrees with the revised data newly acquired by one of the original authors. ${ }^{17}$

Table $1 .{ }^{13} \mathrm{C}$ NMR data for the P-phenyl group of $\mathbf{1 1}$

\begin{tabular}{lllllll}
\hline Frequency & Solvent & ipso-C & ortho-C & meta-C & para-C & Ref. \\
\hline $100 \mathrm{MHz}$ & $\mathrm{CDCl}_{3}$ & $129.6(\mathrm{~d}, \mathrm{~J} 98.5)$ & $128.8(\mathrm{~d}, \mathrm{~J} 12.9)$ & $132.3(\mathrm{~s})$ & $132.2(\mathrm{~s})$ & 9 \\
$125 \mathrm{MHz}$ & $\mathrm{C}_{6} \mathrm{D}_{6}$ & $129.6(\mathrm{~d}, \mathrm{~J} 98)$ & $132.3(\mathrm{~s})$ & $128.8(\mathrm{~d}, \mathrm{~J} 13)$ & $132.2(\mathrm{~s})$ & 15 \\
$100 \mathrm{MHz}$ & $\mathrm{CDCl}_{3}$ & $129.6(\mathrm{~d}, \mathrm{~J} 98.7)$ & $128.8(\mathrm{~d}, \mathrm{~J} 12.9)$ & $132.3(\mathrm{~s})$ & $132.2(\mathrm{~s})$ & 16 \\
$75 \mathrm{MHz}$ & $\mathrm{CDCl}_{3}$ & $129.6(\mathrm{~d}, \mathrm{~J} 99)$ & $132.2(\mathrm{~d}, \mathrm{~J} 11)$ & $128.8(\mathrm{~d}, \mathrm{~J} 13)$ & $132.1(\mathrm{~s})$ & this work \\
$125 \mathrm{MHz}$ & $\mathrm{CDCl}_{3}$ & $129.6(\mathrm{~d}, \mathrm{~J} 99)$ & $132.3(\mathrm{~d}, \mathrm{~J} 11)$ & $128.9(\mathrm{~d}, \mathrm{~J} 13)$ & $132.2(\mathrm{~s})$ & 17 \\
\hline
\end{tabular}

\section{Conclusions}

The result of the isotopic labeling experiment indicates that formation of the trioxo bis(ylide) 6 from both 4 and 5 proceeds by initial loss of $\mathrm{CO}_{2}$ or $\mathrm{COS}$ respectively to give ylide 7 . This undergoes both loss of $\mathrm{CO}$ to afford the ketene ylide $\mathbf{1 1}$ and ring-opening to the dipolar species $\mathbf{9}$ which then combine in a cycloaddition reaction to form 6. Purely thermal cyclotrimerisation of the ketene ylide $\mathbf{1 1}$ to give $\mathbf{1 2}$ has been observed and correct interpretation of the ${ }^{13} \mathrm{C}$ NMR data for $\mathbf{1 1}$ shows this to be consistent with the usual pattern of chemical shifts and $\mathrm{P}-\mathrm{C}$ coupling constants for triphenylphosphonium ylides.

\section{Experimental Section}

General. Melting points were determined using a Reichert hot-stage microscope and are uncorrected. NMR spectra were recorded using a Varian Gemini 2000 instrument at $300 \mathrm{MHz}$ for ${ }^{1} \mathrm{H}, 75 \mathrm{MHz}$ for ${ }^{13} \mathrm{C}$, and 121 $\mathrm{MHz}$ for ${ }^{31} \mathrm{P}$. All spectra were recorded on solutions in $\mathrm{CDCl}_{3}$ with internal $\mathrm{Me}_{4} \mathrm{Si}$ as reference for ${ }^{1} \mathrm{H}$ and ${ }^{13} \mathrm{C}$ and external $\mathrm{H}_{3} \mathrm{PO}_{4}$ as reference for ${ }^{31} \mathrm{P}$. Chemical shifts $(\delta)$ are given in ppm to high frequency from the reference and coupling constants $(J)$ are in $\mathrm{Hz}$. Flash vacuum pyrolysis was performed using the set-up previously described. ${ }^{18}$ Compounds $4,{ }^{4} 5,{ }^{5}$ and $11^{8,9}$ were prepared by the published methods. 
Flash Vacuum Pyrolysis of 4. FVP of $4(36.5 \mathrm{mg})$ at $400{ }^{\circ} \mathrm{C}$ and $10^{-2}$ Torr gave a brown solid at the furnace exit that was mainly $\mathrm{Ph}_{3} \mathrm{PO}\left(\delta_{\mathrm{P}}+29.2\right)$ and gaseous products in the cold trap that condensed as a white solid. Addition of methanol to the cold trap followed by warming to RT did not result in trapping of any reactive products and no phosphorus compounds were present.

Repeat FVP of $4\left(320 \mathrm{mg}\right.$ ) at $200{ }^{\circ} \mathrm{C}$ and $10^{-2}$ Torr gave a white solid at the furnace exit that proved to be a $5: 3$ mixture of $\mathrm{Ph}_{3} \mathrm{PO}$ and $\mathrm{Ph}_{3} \mathrm{P}\left(\delta_{\mathrm{P}}-5.0\right)$. In the inlet tube a pink solid was left which proved to be 3,5bis(triphenyphosphoranylidene)cyclopentane-1,2,4-trione $6(22 \mathrm{mg}, 9 \%) .{ }^{1} \mathrm{H}$ NMR: $\delta_{\mathrm{H}} 7.40-7.75(30 \mathrm{H}, \mathrm{m}) .{ }^{13} \mathrm{C}$ NMR: $\delta_{c} 67.6(d d, J 112,4, P=C), 124.6(d, J$ 92, C-1 of Ph), 128.5 (d, J 13, C-3 of Ph), 132.3 (d, J 2, C-4 of Ph), 134.1 (d, J 11, C-2 of Ph), 187.6 (dd, J 20, 6, 1,2-CO), 196.4 (t, J 10, 4-CO). ${ }^{31} \mathrm{P}$ NMR: $\delta_{\mathrm{P}}+9.0$ (Lit., ${ }^{7}+8.8$ ).

Flash Vacuum Pyrolysis of 5. FVP of $5(29 \mathrm{mg})$ at $600{ }^{\circ} \mathrm{C}$ and $10^{-2}$ Torr gave a white solid at the furnace exit which was shown by ${ }^{1} \mathrm{H}$ and ${ }^{31} \mathrm{P}$ NMR to consist of small amounts of $\mathrm{Ph}_{3} \mathrm{PO}, \mathrm{Ph}_{3} \mathrm{PS}\left(\delta_{\mathrm{P}}+43.6\right)$ and mainly ketenylidenetriphenylphosphorane $11\left(\delta_{\mathrm{P}}+5.7\right)$.

Solution Pyrolysis of 4. A solution of $4(44 \mathrm{mg})$ in diphenyl ether $(2 \mathrm{~mL})$ was heated under reflux for $30 \mathrm{~min}$. The solvent was removed by kugelrohr distillation to leave a dark coloured residue shown by ${ }^{1} \mathrm{H}$ and ${ }^{31} \mathrm{P} N M \mathrm{R}$ to consist mainly of bis(ylide) 6 together with a little $\mathrm{Ph}_{3} \mathrm{PO}$.

Solution Pyrolysis of 5. A solution of $5(20 \mathrm{mg})$ in diphenyl ether $(1 \mathrm{~mL})$ was heated under reflux for $4 \mathrm{~h}$. The solvent was removed by Kugelrohr distillation to leave a dark coloured residue shown by ${ }^{1} \mathrm{H}$ and ${ }^{31} \mathrm{P} N M R$ to consist mainly of bis(ylide) 6 together with a little $\mathrm{Ph}_{3} \mathrm{PO}$.

Neat Pyrolysis of 4. A sample of $4(20 \mathrm{mg})$ was heated in a kugelrohr distillation apparatus at $250{ }^{\circ} \mathrm{C}$ for $1.5 \mathrm{~h}$. The resulting dark coloured solid was shown by ${ }^{1} \mathrm{H}$ and ${ }^{31} \mathrm{P}$ NMR to consist mainly of bis(ylide) 6.

Neat Pyrolysis of 5. A sample of 5 (10 mg) was heated in a kugelrohr distillation apparatus at $250{ }^{\circ} \mathrm{C}$ for $3 \mathrm{~h}$. The resulting dark coloured solid was shown by ${ }^{1} \mathrm{H}$ and ${ }^{31} \mathrm{P}$ NMR to consist mainly of unchanged 5 .

Solution Pyrolysis of 4 and 11 Together. A solution of 4 (40 mg, $0.11 \mathrm{mmol})$ and $11(32 \mathrm{mg}, 0.11 \mathrm{mmol})$ in diphenyl ether $(1 \mathrm{~mL})$ was heated under reflux for $2 \mathrm{~h}$. The resulting dark coloured solution was shown by ${ }^{31} \mathrm{P}$ NMR to contain 6 (20\%) in addition to $\mathrm{Ph}_{3} \mathrm{PO}$ and $\mathrm{Ph}_{3} \mathrm{P}$.

Solution Pyrolysis of 11. A solution of $11(46 \mathrm{mg})$ in diphenyl ether $(1.5 \mathrm{~mL})$ was heated under reflux for 30 min. The dark solution was shown by ${ }^{31} \mathrm{P} N \mathrm{NMR}$ to contain $\mathrm{Ph}_{3} \mathrm{PO}, \mathrm{Ph}_{3} \mathrm{P}$ and 2,4,6tris(triphenylphosphoranylidene)cyclohexane-1,3,5-trione $12\left(\delta_{\mathrm{p}}+13.9\right)$.

Neat Pyrolysis of 11. Compound $11(250 \mathrm{mg})$ was heated in a kugelrohr distillation apparatus at $200^{\circ} \mathrm{C}$ for $3 \mathrm{~h}$. After this time a vacuum was applied and a colourless oil distilled off which proved to be $\mathrm{Ph}_{3} \mathrm{PO}$. The dark residue was mainly 2,4,6-tris(triphenylphosphoranylidene)cyclohexane-1,3,5-trione $12(60 \%) .{ }^{13} \mathrm{C} \mathrm{NMR:} \delta_{\mathrm{C}} 74.3$ (dt, J 116, 10, P=C), 127.6 (d, J 12, C-3 of Ph), 128.3 (d, J 91, C-1 of Ph), 130.4 (C-4 of Ph), 133.6 (d, J 10, C-2 of Ph), 184.3 (CO). ${ }^{31}$ P NMR: $\delta_{p}+13.4$ (Lit., ${ }^{7}+13.7$ ).

(Methoxycarbonylmethyl)tri-p-tolylphosphonium bromide (15). To a stirred solution of tri- $p$-tolylphosphine ${ }^{11}$ $(2.0 \mathrm{~g}, 6.6 \mathrm{mmol})$ in dry toluene $(40 \mathrm{~mL})$ a solution of methyl bromoacetate $(1.0 \mathrm{~g}, 6.6 . \mathrm{mmol})$ in dry toluene $(20 \mathrm{~mL})$ was added dropwise. After stirrring at RT for $18 \mathrm{~h}$, the resulting white precipitate was filtered off and washed with diethyl ether to give the product $(2.6 \mathrm{~g}, 87 \%)$ as a white powder, mp $187-189{ }^{\circ} \mathrm{C} .{ }^{1} \mathrm{H} N M R: \delta_{H}$ $2.48(9 \mathrm{H}, \mathrm{s}, \mathrm{Me}), 3.59(3 \mathrm{H}, \mathrm{s}, \mathrm{OMe}), 5.37\left(2 \mathrm{H}, \mathrm{d}, J 12, \mathrm{P}-\mathrm{CH}_{2}\right), 7.39-7.50(6 \mathrm{H}, \mathrm{m}), 7.66-7.80(6 \mathrm{H}, \mathrm{m}) .{ }^{13} \mathrm{C} \mathrm{NMR:} \delta_{\mathrm{C}}$ 21.8 (Me), 33.0 (d, J 58, P-CH ), 53.2 (OMe), 114.6 (d, J 92, C-1 of Tol), 130.9 (d, J 14, C-3 of Tol), 133.7 (d, J 11 , C-2 of Tol), 146.3 (d, J 3, C-4 of Tol), 165.2 (C=0). ${ }^{31}$ P NMR: $\delta_{P}+20.2$.

(Methoxycarbonylmethylene)tri-p-tolylphosphorane (16). A solution of the salt 15 (2.5 g, 5.5 mmol) in water $(20 \mathrm{~mL})$ was stirred rapidly while $\mathrm{NaOH}(0.22 \mathrm{~g}, 5.5 \mathrm{mmol})$ was added. The resulting mixture was extracted with ethyl acetate $(3 \times 10 \mathrm{~mL})$ and the extract was dried and evaporated to give the title compound (1.6 g, $77 \%$ ) as a yellow solid, $\mathrm{mp} 85-87^{\circ} \mathrm{C}$. IR (Nujol, $v_{\max }, \mathrm{cm}^{-1}$ ): $1728,1271,1118,808 .{ }^{1} \mathrm{H}$ NMR: $\delta_{\mathrm{H}} 2.38(9 \mathrm{H}, \mathrm{s}, \mathrm{Me})$, 
$3.40(1 \mathrm{H}, \mathrm{br} \mathrm{s},=\mathrm{CH}), 3.52(3 \mathrm{H}, \mathrm{s}, \mathrm{OMe}), 7.20-7.36(6 \mathrm{H}, \mathrm{m}), 7.48-7.65(6 \mathrm{H}, \mathrm{m}) .{ }^{13} \mathrm{C} \mathrm{NMR:} \delta_{\mathrm{C}} 21.4(\mathrm{Me}), 30.4(\mathrm{~d}, J$ 119, P=C), 49.8 (OMe), 123.5 (d, J 96, C-1 of Tol), 129.4 (d, J 13, C-3 of Tol), 132.8 (d, J 10, C-2 of Tol), 142.5 (C4 of Tol), 170.8 (d, J 11, C=0). ${ }^{31} \mathrm{P}$ NMR: $\delta_{\mathrm{p}}+16.7 . \mathrm{MS}(\mathrm{Cl}) \mathrm{m} / z 377\left(\mathrm{M}^{+}, 34 \%\right), 361(6), 345$ (24), 321 (100), 305 (11). HRMS: $\mathrm{C}_{24} \mathrm{H}_{26} \mathrm{O}_{2} \mathrm{P}(\mathrm{M}+\mathrm{H})$ requires 377.1670. Found: 377.1665 .

Tri-p-tolylphosphoranylideneketene (17). A solution of ylide 16 (0.95 g, $2.5 \mathrm{mmol}$ ) was stirred in dry toluene $(10 \mathrm{~mL})$ under nitrogen while sodium amide $(0.34 \mathrm{~g}, 8.7 \mathrm{mmol})$ was added. The mixture was heated under reflux under nitrogen for $24 \mathrm{~h}$ then cooled and filtered under nitrogen. Evaporation of the filtrate gave a solid containing tri-p-tolylphosphine oxide $\left(\delta_{\mathrm{p}}+29.4\right)$ and the title product $(0.4 \mathrm{~g}, 46 \%) .{ }^{13} \mathrm{C}$ NMR: $\delta_{\mathrm{C}} 142.6$ (d, J 39 , $\mathrm{P}=\mathrm{C}=\mathrm{C}=0) .{ }^{31} \mathrm{P}$ NMR: $\delta_{\mathrm{P}}+5.3$.

Attempted Pyrolysis of $\mathbf{1 7}$ with 4 or on its own. All attempts at solution pyrolysis of 17, either with or without added 4, in boiling diphenyl ether, as well as neat pyrolysis of 17 in a kugelrohr oven at $170{ }^{\circ} \mathrm{C}$, gave tri-ptolylphosphine oxide as the only significant phosphorus-containing product.

${ }^{13}$ C-Labelled Methyl Bromoacetate. Thionyl chloride $(9.3 \mathrm{~g}, 5.7 \mathrm{~mL}, 78 \mathrm{mmol})$ was added dropwise to a solution of $20 \%{ }^{13} \mathrm{C}$-CO-labelled bromoacetic acid $(5.0 \mathrm{~g}, 36 \mathrm{mmol})$ in methanol $(50 \mathrm{~mL})$ and the mixture was stirred at RT for $2 \mathrm{~h}$. Evaporation followed by distillation at atmospheric pressure gave the product as a colourless liquid, bp $135-140{ }^{\circ} \mathrm{C} .{ }^{1} \mathrm{H}$ NMR: $\delta_{\mathrm{H}} 2.92(3 \mathrm{H}, \mathrm{s}, \mathrm{OMe}), 2.95\left(2 \mathrm{H}, \mathrm{s}, \mathrm{CH}_{2}\right) .{ }^{13} \mathrm{C}$ NMR: $\delta_{\mathrm{C}} 25.5\left(\mathrm{CH}_{2}\right), 53.2$ (OMe), 167.7 (CO, $20 x$ enhanced compared to unlabelled material).

${ }^{13}$ C-CO Labelled (Methoxycarbonylmethylene)triphenylphosphonium Bromide (18). A solution containing labelled methyl bromoacetate $(5.0 \mathrm{~g}, 33 \mathrm{mmol})$ and triphenylphosphine $(8.56 \mathrm{~g}, 33 \mathrm{mmol})$ in dry toluene (30 $\mathrm{mL}$ ) was stirred at RT for $48 \mathrm{~h}$. The resulting solid was filtered off and dried to give the title product (11.03 $\mathrm{g}$, $81 \%$ ) as colourless crystals, mp $161-162{ }^{\circ} \mathrm{C}$ (Lit., ${ }^{19} 163{ }^{\circ} \mathrm{C}$ ). ${ }^{13} \mathrm{C}$ NMR: $\delta_{\mathrm{C}} 32.7$ (d, J 57, $\left.\mathrm{CH}_{2}\right), 53.2$ (OMe), 117.5 (d, J 89, C-1 of Ph), 130.1 (d, J 13, C-3 of Ph), 133.7 (d, J 11, C-2 of Ph), 135.0 (d, J 2, C-4 of Ph), 164.8 (d, J 3, $\mathrm{C}=0,20 \mathrm{x}$ enhanced). ${ }^{31} \mathrm{P}$ NMR: $\delta_{\mathrm{P}}+22.8$ (Lit., $\left.{ }^{20}+20.3\right)$.

$20 \%{ }^{13} \mathrm{C}$-CO Labelled (Methoxycarbonylmethylene)triphenylphosphorane (19). A solution of the salt 18 (4.0 $\mathrm{g}, 9.6 \mathrm{mmol})$ in water $(30 \mathrm{~mL})$ was stirred rapidly while $\mathrm{NaOH}(0.39 \mathrm{~g}, 9.6 \mathrm{mmol})$ was added. The resulting mixture was extracted with ethyl acetate $(3 \times 10 \mathrm{~mL})$ and the extract was dried and evaporated to give the title compound ( $2.6 \mathrm{~g}, 81 \%$ ) as a white solid, $\mathrm{mp} 163-164{ }^{\circ} \mathrm{C}$ (Lit., $\left.{ }^{19} 162-163{ }^{\circ} \mathrm{C}\right) .{ }^{13} \mathrm{C}$ NMR: $\delta_{\mathrm{C}} 29.7(\mathrm{~d}, J 127, \mathrm{P}=\mathrm{C})$, 49.6 (OMe), 127.7 (d, J 91, C-1 of Ph), 128.6 (d, J 12, C-3 of Ph), 131.8 (C-4 of Ph), 132.8 (d, J 10, C-2 of Ph), 171.5 (d, J 12, C=0, 20 x enhanced). ${ }^{31}$ P NMR: $\delta_{p}+18.2$ (Lit., $\left.{ }^{13}+17.6\right)$.

$20 \%{ }^{13} \mathrm{C}$-CO Labelled Triphenylphosphoranylideneketene (20). A solution of labelled ylide 19 (1.4 g, $\left.4.2 \mathrm{mmol}\right)$ was stirred in dry toluene $(7 \mathrm{~mL})$ under nitrogen while sodium amide $(0.40 \mathrm{~g}, 10 \mathrm{mmol})$ was added. The mixture was heated under reflux under nitrogen for $48 \mathrm{~h}$ then cooled and filtered under nitrogen. Evaporation of the filtrate gave a solid containing a 1:2 mixture of triphenylphosphine oxide $\left(\delta_{\mathrm{P}}+29.2\right)$ and the title product (0.63 g, 50\%). ${ }^{13} \mathrm{C}$ NMR: $\delta_{\mathrm{C}}-10.5$ (d, J 189, P=C), 128.8 (d, J 13, C-3 of Ph), 129.6 (d, J 99, C-1 of Ph), 132.1 (C-4 of $\mathrm{Ph}$ ), 132.2 ( $d, J 11, \mathrm{C}-2$ of $\mathrm{Ph}$ ), 145.6 (d, J 43, $\mathrm{P}=\mathrm{C}=\mathrm{C}=\mathrm{O}, 20 \mathrm{x}$ enhanced). ${ }^{31} \mathrm{P}$ NMR: $\delta_{\mathrm{P}}+5.6$ (Lit., $\left.{ }^{21}+5.4\right)$.

Solution Pyrolysis of 4 and 20 Together. A solution of 4 (210 mg, $0.56 \mathrm{mmol})$ and 20 (170 mg, $0.56 \mathrm{mmol})$ in diphenyl ether $\left(4 \mathrm{~mL}\right.$ ) was heated under reflux for $2 \mathrm{~h}$. The resulting dark coloured solution was shown by ${ }^{31} \mathrm{P}$ NMR to contain (a labelled version of) $6\left(\delta_{P}+9.1\right)$ in addition to $\mathrm{Ph}_{3} \mathrm{PO}$ and $\mathrm{Ph}_{3} \mathrm{P}$. In the carbonyl region of the ${ }^{13} \mathrm{C}$ NMR spectrum the signal at $\delta_{\mathrm{C}} 196.0(\mathrm{t}, J 9,4-\mathrm{CO})$ showed a $20 \mathrm{x}$ enhancement compared to the signal at $\delta_{c} 187.2(d d, J 20,6,1,2-C O)$, i.e. corresponding to structure 21 and not 22. 


\section{Acknowledgements}

We are grateful to the late Professor H. J. Bestmann (Erlangen) for helpful discussions and for providing authentic samples of compounds 6 and 12, to Professor Rainer Schobert (Bayreuth) for confirming our conclusions on the published ${ }^{13} \mathrm{C}$ NMR data for 11 and to EPSRC and Glaxo-Wellcome (now GSK) for their support of this work through a CASE Studentship to TM.

\section{References}

1. Aitken, R. A.; Boubalouta, Y.; Chang, D.; Cleghorn, L. P.; Gray, I. P.; Karodia, N.; Reid, E. J.; Slawin, A. M. Z. Tetrahedron, 2017, 73, in press.

2. Aitken, R. A.; Massil, T. Progr. Heterocycl. Chem. 2000, 12, 22-36. http://dx.doi.org/10.1016/S0959-6380(00)80004-5

3. Aitken, R. A.; Buchanan, G. M.; Karodia, N.; Massil, T.; Young, R. J. Tetrahedron Lett. 2001, 42, $141-144$. http://dx.doi.org/10.1016/S0040-4039(00)01905-5

4. Schmidt, A. H.; Goldberger, W.; Dümmler, M.; Aimène, A. Synthesis 1988, 782-785. http://dx.doi.org/10.1055/s-1988-27706

5. Bjørnstad, V.; Frøyen, P.; Hope, H.; Skramstad, J. Article 044, "Electronic Conference on Heterocyclic Chemistry 96", Rzepa, H. S.; Snyder, J.; Leach, C. Eds., Royal Society of Chemistry, 1997 (see http://www.ch.ic.ac.uk/ectoc/echet96/papers/044/index.htm).

6. Reinecke, M. G. Tetrahedron 1982, 38, 427-498. http://dx.doi.org/10.1016/0040-4020(82)80092-6

7. Bestmann, H. J.; Fürst, T. G.; Schier, A. Angew. Chem. Int. Ed. Engl. 1993, 32, 1747-1750. http://dx.doi.org/10.1002/anie.199317471

8. Bestmann, H. J.; Schmidt, M.; Schobert, R. Synthesis 1988, 49-53. http://dx.doi.org/10.1055/s-1988-27461

9. Schobert, R. Org. Synth. 2005, 82, 140-145. http://dx.doi.org/10.15227/orgsyn.082.0140

10. Fürst, T. PhD Thesis, University of Erlangen-Nürnberg, 1994.

11. Michaelis, A. Liebigs Ann. Chem. 1901, 315, 43-103. http://dx.doi.org/10.1002/jlac.19013150105

12. Werkhoven, T. M.; van Nispen, R.; Lugtenburg, J. Eur. J. Org. Chem. 1999, 2909-2914. http://dx.doi.org/10.1002/(SICI)1099-0690(199911)1999:11<2909::AID-EJOC2909>3.0.CO;2-5

13. Matthews, C. N.; Birum, G. H. Tetrahedron Lett. 1966, 5707-5710. http://dx.doi.org/10.1016/S0040-4039(01)84182-4

14. Birum, G. H.; Matthews, C. N. J. Am. Chem. Soc. 1968, 90, 3842-3847.

http://dx.doi.org/10.1021/ja01016a045

15. Boeckman, Jr., R. K.; Pero, J. E.; Boehmler, D. J. J. Am. Chem. Soc. 2006, 126, 11032-11033. http://dx.doi.org/10.1021/ja063532

16. Myrtle, J. D.; Beekman, A. M.; Barrow, R. A. Org. Biomol. Chem. 2016, 14, 8253-8260. http://dx.doi.org/10.1039/c6ob00938g

17. Data newly acquired by Professor R. Schobert (University of Bayreuth), Schobert, R. personal communication, 2017. 
18. Aitken, R. A.; Atherton, J. I. J. Chem. Soc., Perkin Trans. 1 1994, 1281-1284. http://dx.doi.org/10.1039/P19940001281

19. Isler, O.; Gutmann, H.; Monyavon, M.; Rüegg, R.; Ryser, G.; Zeller, P. Helv. Chim. Acta 1957, 40, 12421249.

http://dx.doi.org/10.1002/hlca.19570400515

20. Grim, S. O.; McFarlane, W.; Davidoff, E. F.; Marks, T. J. J. Phys. Chem. 1966, 70, 581-584. http://dx.doi.org/10.1021/j100874a502

21. Bestmann, H. J.; Sandmeier, D. Chem. Ber. 1980, 113, 274-277. http://dx.doi.org/10.1002/cber.19801130129 